\title{
High mountain relief in marble in Pirin Mountains, Bulgaria: structure, specifics and evolution
}

\author{
Emil GACHEV ${ }^{*}$ \\ ${ }^{1}$ South-West University "Neofit Rilski", Blagoevgrad, Bulgaria \\ Received 25 October 2017; Revised 15 November 2017; Accepted 1 December 2017 \\ *Correspondence to: Emil GACHEV, e-mail: emil.gachev@swu.bg
}

\begin{abstract}
The present article is focused on high mountain relief in marble, which combines glacial, periglacial and karstic morphology. High mountain karst is found in Northern Pirin (Vihren and Sinanitsa area) and central Pirin (Orelek area), the latter lacking traces of glaciation due to its low altitude. In the most representative area, Vihren part, several vast and deep cirques-uvalas were formed, which comprise a large diversity of landforms. Main factor for the specifics of relief in marble is the structure of the rock, which combines carbonate mineral content and crystalline properties; they favour both the occurrence of karstification and frost weathering. The high elevation of Northern Pirin (up to $2914 \mathrm{~m}$ a.s.l.), and the resulting extensive former glaciation enhanced the karst processes by weathering of the morphological surface. At present, surface karst is most developed on elevated sections of cirque bottoms, which were ice free before the beginning of the Holocene and are away from rockfall creep accumulation. A special element of glaciokarstic relief in Pirin are the summer lasting snow/ice features (glacierets and snow patches), two of which are considered centuries old, and still survive despite the temperature warming. In general, karst processes in the high mountain areas of Pirin are less developed than in the western part of the Balkan Peninsula (the Dinarides), due to the greater susceptibility of marble to physical weathering compared to limestone, which leads to a more intensive formation of regolith on the surface, and in result of the generally colder and dryer climate.
\end{abstract}

KEYWORDS

Glaciokarst; marble; sinkholes; glacierets; frost weathering; Pirin; Bulgaria

\section{Introduction}

High mountain karst is karst which is formed and functions under high mountain climatic and environmental conditions (Djurović, 2011; Djurović et al., 2010), typical with low temperatures, long 
snow cover duration, and scarce or no vegetation (Meneghel and Sauro, 1990). The term can be applied within the spatial framework of our region, where as high mountain can be categorized mostly the subalpine and alpine areas positioned above the natural treeline, in the case of Pirin mountain, about $2000 \mathrm{~m}$.

In general, glaciokarst is a karst area transformed by glaciers (Maire, 1978; Kunaver, 1983, 2009; Smart, 2004; Veress, 2016). This is a specific type of karst environment, which is observed in high latitudes and high altitudes of the world. Glaciokarst can function only if vertical karst drainage of subglacial waters is active, which results in specific functioning of glaciers as well as in formation of typical geomorphic features. On the other hand, inert vertical karst drainage prevents functioning of glaciokarst and causes only subglacial and postglacial surface modification by dissolution, which is referred to as karsti-glacial action (Žebre and Stepišnik, 2014).

Glaciokarst is spread on numerous high mountain locations throughout South-Eastern Europe. As the present glaciation in this region is restricted to several smallest scale features (glacierets), this type of relief can be categorized as deglaciated karst. Within this context glaciokarstic landscapes encompass karst features and hydrology, as well as inherited erosional features and deposits from former glaciations (Žebre and Stepišnik, 2015). Glaciokarstic forms have been developed on the background of glacial topography, formed during Pleistocene cold phases and the subsequent retreat stages in the Lateglacial and the Holocene.

As at present the main geomorphic process is the chemical denudation exerted by the mainly vertically moving atmospheric waters, glaciokarstic areas are typical with the good preservation of surface landforms, in particular those left by former glaciers (Žebre and Stepišnik, 2015). This is an advantage when trying to reconstruct the evolution of relief.

In the south-eastern part of the Balkan Peninsula (within the Thrace-Macedonian massif) glaciokarst is mostly developed not in limestone or dolostone, as it is in the Dinaric and Pindus mountain chains, but in marble instead. Marble is carbonate and crystalline rock at the same time, combining features of both. In the climate conditions of the high mountain this leads to the joint action of frost weathering and karstification, and often local topography is what determines which process prevails. Thus a great diversity of landforms is generated.

Glaciokarst and high mountain karst are two different concepts. On one hand, high mountain karst includes also the areas in the subalpine and the alpine belt that were weakly (or possibly not) affected by Pleistocene glaciers - summit surfaces, nunataks, southern slope sections, etc. On the other hand, glaciokarst comprises the formerly glaciated valley sections that descend far below the high mountain belt. However, complete and proper investigation of the maximum extent of Pleistocene glaciers has still not been done for Pirin Mountains, and that is one reason for the present study to be focused not on glaciokarst, but on high mountain karst (at altitudes above $2000 \mathrm{~m}$ a. s. I.) instead.

There are various discrepancies throughout different parts of Pirin between glaciokarst and high mountain karst, as, according to author's own observations, glaciers were supposed to have descended to altitudes below $1500 \mathrm{~m}$ along the north heading valleys of Northern Pirin, while in Middle Pirin, which is slightly higher than 2000 m, there are lacking any signs of former glaciation (Georgiev, 1991). The present study aims to make the first specialized overview of high mountain karst geomorphological complexes in Pirin Mountain, focusing on glaciokarst, to outline their specifics (climate-related also) that distinguish them from classical limestone and dolomite high mountain relief, and to specify the contemporary trends in the development of these unique landscapes.

\section{Study Areas}

In the Balkan Peninsula, marble is wide spread, especially in the southern areas, known as ThraceMacedonian massif. Few places built of marble however exceed the elevation of $2000 \mathrm{~m}$ a.s.l.

The most prominent high mountains where marble karst is spread are Pirin (Bulgaria, $2914 \mathrm{~m}$ 
a.s.l.), Olympus (Greece, $2917 \mathrm{~m}$ a.s.l.), Slavianka/Orvilos (Bulgaria/Greece, 2212 m a.s.l.), Falakro (2232 m a.s.l.) and Mt. Athos (Greece, 2033 $\mathrm{m}$ a.s.l.). This type of relief is most pronounced in Pirin and Olympus, which in their highest parts reach above $2900 \mathrm{~m}$ a.s.l. Pirin Mountains are the second highest in Bulgaria and the third in the Balkans. They are located in the southwest part of the country, and have a generally rhomboidal shape $(70 \times 35 \mathrm{~km})$ with the longer axis running in NNESSW direction. The highest point, Mt. Vihren (2914 $m$ a.s.l.), is situated in the northern part of the mountain range. Two more locations in the central section rise above $2800 \mathrm{~m}$ a.s.l., and the higher than $2500 \mathrm{~m}$ a.s.l. has a considerable extent. Like most of the mountains in this part of the Balkans, Pirin has a complex geological structure. Three granitic intrusions of Late Cretacious-Paleogene age (Vatsev, 2005) build up the core of the massif: one in the farthest north, one in the centre, and one in the south.

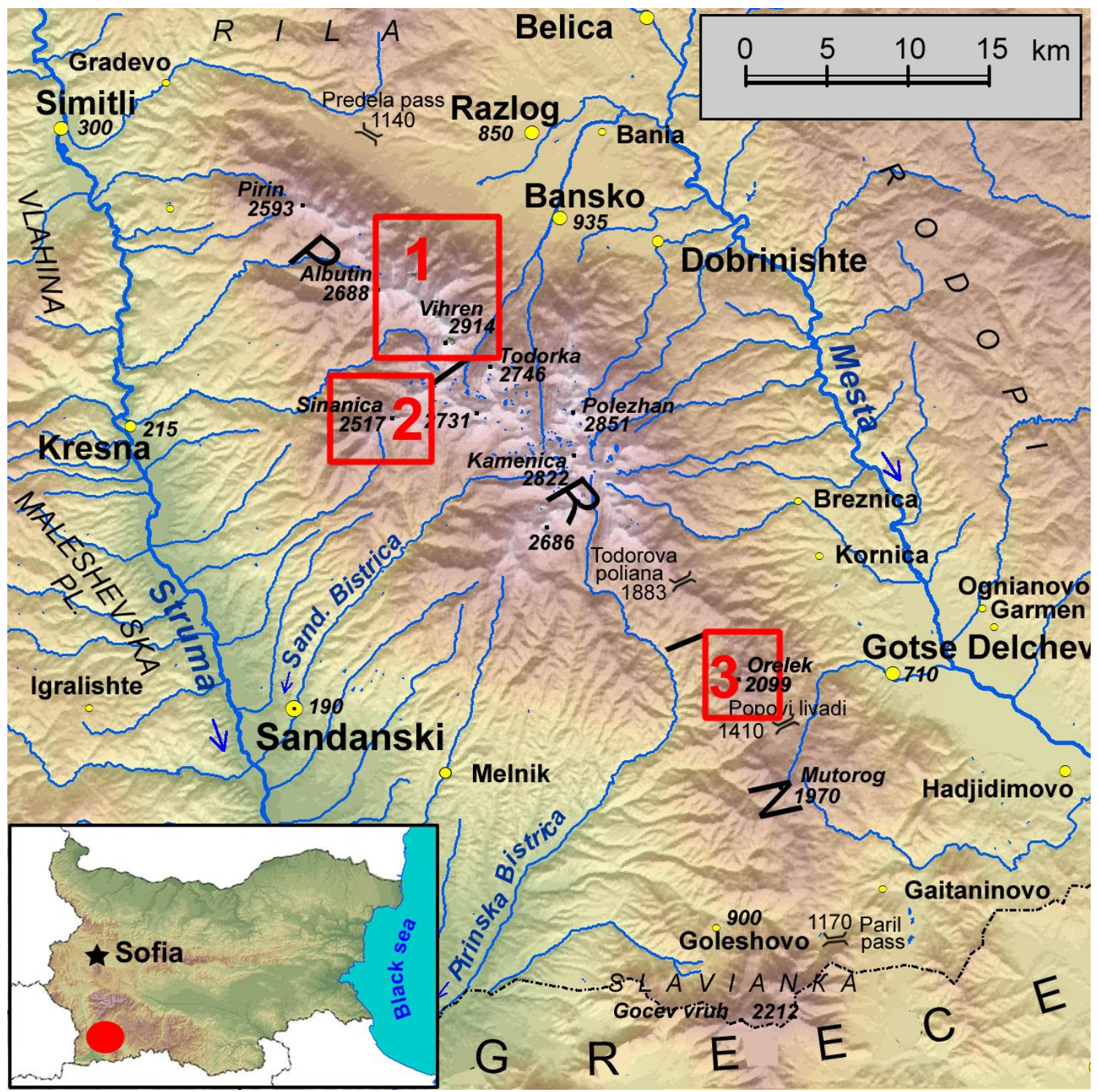

Figure 1 Pirin mountains with study areas: 1) Vihren, 2) Sinanitsa, 3) Orelek (figures next to settlements indicate their altitude) 
Around, and between them, the mantle of metamorphic rocks includes gneisses, schists, amphibolites, and marble. Their metamorphism is addressed to the Alpine orogenic cycle (Ivanov et al., 2000). Paleogene and neogene sedimentary rocks are exposed in the periphery, which is surrounded from all sides by faults, producing a classical horst structure. Volcanic rocks occupy the far east of the area. They are a result of eruptive activities along the Mesta graben during the Paleogene (Vatsev and Nedyalkova, 1983).

In Pirin Mountains marble is found in three main areas: the ridges around Vihren peak to the north, which is the highest section in all Pirin, and here marbles have their largest extent, the area of Orelek peak to the south, and the small spot around Sinanitsa peak to the west (Fig. 1).

In Vihren area marbles occupy 2298 ha at altitudes above $2000 \mathrm{~m}$ a.s.l. (in projective area), which is $95 \%$ of the total area of high mountain karst in Pirin. This is the main ridge and the northeastern mountain slope between the saddles Preslapa (south of Vihren peak) to the south and Suhodolski preval to the north. This is a high mountain section about $5 \mathrm{~km}$ long (the lowest point at $2650 \mathrm{~m}$ a.s.l.) which includes the highest peaks in Pirin: Vihren (2914 m a.s.l.), Kutelo (2908 m a.s.l.), Banski suhodol (2884 $\mathrm{m}$ a.s.l.) and Bayuvi dupki (2856 $\mathrm{m}$ a.s.l.). Five vast cirques were carved on the northern slope. From south (SE) to north (NW) these are: Kazanite (Goliam Kazan and Malak Kazan), Kutelo, Banski suhodol, Bayuvi dupki, Kamenitica. Futher west on that slope there is the contact with the granites of the northern plutonic body, and marbles occupy parts of the cirques and valleys of Razlozhki suhodol and Albutin. On the southern (SW) mountain slope marbles occupy just the uppermost section and the ridgetop, while the lower areas comprise a contact strip between marble and granite.

In Orelek area the surface lying above $2000 \mathrm{~m}$ is very small - 30 ha. Here is the highest mountain in the southern parts of Pirin, Orelek (2099 m a.s.l.) (in Bulgarian geography it is termed "Middle Pirin", but it is situated to the south of the largest and highest part of the mountain). The area represents a typical uplifted karst plateau, with the highest peak rising slightly at its western end and the main ridge spreading from north to south. Western slopes drop down steeply.

In the western part of Northern Pirin Mountains marbles are spread in the area of Sinanitsa Peak (2517 $\mathrm{m}$ a.s.l.) and build up just a single wall in the next cirque of Georgiitsa Peak (2589 m a.s.l.). The total area in marble above $2000 \mathrm{~m}$ a.s.l. in this location is 95 ha.

\section{Methods of research}

This paper presents revised results from more than 10-year research of high mountain karst features in Pirin Mountains. Descriptive methods involved the use of aerial photographs and satellite images, as well as detail work on the field: photographing, description and mapping. The size of the two perennial firn fields (glacierets) has been monitored on a yearly basis. The size (area) of Snezhnika glacieret near Vihren peak has been measured with a rope every autumn since 2008 . The area of the glacieret in Banski suhodol cirque was measured with a rope in 2009, and since 2011 ice variation has been recorded according to five fixed positions, marked on the field. Repetitive photography from same positions has been applied to both glacierets to monitor short-term dynamics and long-term changes. A geophysical survey was performed on Banski suhodol glacieret in August 2017 in order to estimate its maximum thickness, with the cooperation of Romanian team lead by Prof. Alexandru Onaca from the West University of Timișoara.

In-situ climatic measurements were organized at several sites in the area: on Vihren Peak air temperature and humidity has been measured since October 2014, ground temperature at Vihren Peak and Golemia Kazan cirque since September 2016, and ground temperature near Banski suhodol glacieret since October 2017.

\section{High mountain karst in marble: specifics}

High mountain karst in Pirin differs from the classical limestone karst of the high Dinarides, which can be used for comparison to evaluate the specifics 
of the former. This is due to two main factors: the peculiar properties of marble as bedrock, and the differences in climate.

Marble is a low-grade metamorphic rock, originating from limestone or dolostone. During metamorphism calcite minerals recrystallize, creating an interlocking mosaic of crystals. At the same time, the primary structure of initial sedimentary rocks is mostly destroyed. Pirin marbles are usually very white in colour, which indicates for the silicate poverty of the protolith (Marinova and Zagorchev, 1993) and results in a very high albedo.

As a product of metamorphism, marble has obtained structural features that bring some similarities to other crystalline rocks, including those with silicate composition (such as gneiss, granite, etc.). These concern the tendency to develop cracks at right angles, and fragment on larger angular blocks under the action of physical weathering rather than on pebble size particles, as it is with limestone. In such particular structural frameworks, marble could be more prone to physical weathering (especially frost action) than limestone. This leads to the consequence that in high-mountain marble areas frost defragmentation is strongly pronounced and is often predominant on slopes and ridges (Fig. 2).

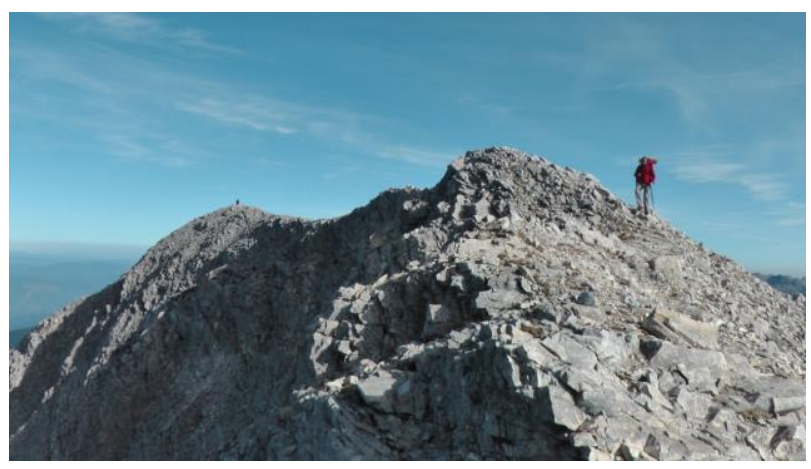

Figure 2 Typical disintegration of marble due to frost weathering

Areas with a low tilt, which were previously in the active zone of frost processes, but later came out of it in the course of post Ice Age warming, have been subject of soil formation, they are smoothened and covered with grass. This additionally slows down the development of surface karst (Fig. 3).
By the specific levels of temperature and precipitation, climate is by no doubt the other major factor for the different appearance of high mountain karst in Pirin compared to its limestone counterparts in the Dinaric, Alpine and other areas.

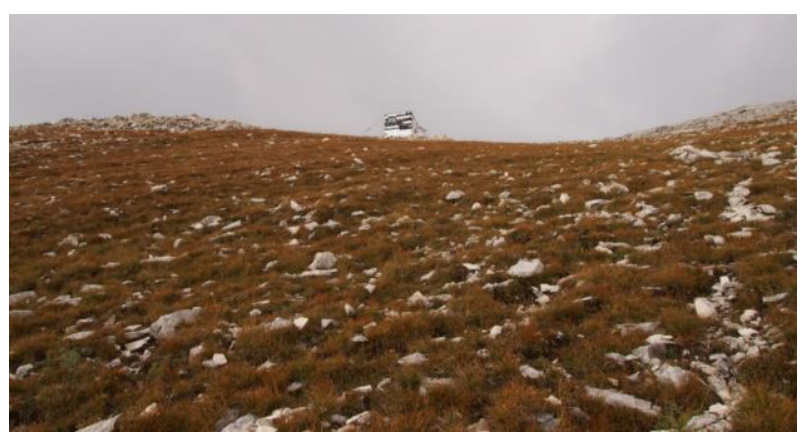

Figure 3 Smooth grassy surfaces: a result of enhanced loose material and soil formation

According to climatic data average air temperature at Sandanski (190 $\mathrm{m}$ a.s.I.) in the SW foot of Pirin, is $13.9^{\circ} \mathrm{C}$ for the standard period (1961-1990), $14.5^{\circ} \mathrm{C}$ for the period $1997-2016$, and $14.8^{\circ} \mathrm{C}$ for 2007-2016 (www.stringmeteo.com). Representative temperature data for the high mountain area can be obtained from the station at Musala Peak in Rila (2925 m a.s.l., 55 km away from the highest peak of Pirin), which has been in operation without an interruption since 1933. The averages for this location are: $-3.0^{\circ} \mathrm{C}$ for $1961-1990$, $-2.2^{\circ} \mathrm{C}$ for $1997-2016$, and $-1.8^{\circ} \mathrm{C}$ for $2007-2016$ (www.stringmeteo.com). According to the data, an average increase of $1^{\circ} \mathrm{C}$ has been registered for the last decade according to the standard period. For the first 22 months of operation, the logger at Vihren Peak (2914 $\mathrm{m}$ a.s.l.) has registered temperatures about $0.5^{\circ} \mathrm{C}$ higher than those at Musala peak (2925 m a.s.l.) (Grunewald et al., 2016), with a good correlation between the daily data $(+0.95)$. This means that for the last decade the averages for the highest peaks of Pirin have been in the range of -1 to $-1.5^{\circ} \mathrm{C}$. Automatic device installed at Vihren hut at $1970 \mathrm{~m}$ a.s.l. by German scientists from Dresden show average temperatures for 20102015 of about $+4.9^{\circ} \mathrm{C}$ (Grunewald et al., 2016), which means that in the last years air temperatures at the lower margin of high mountain belt $(2000 \mathrm{~m}$ a.s.l.) are about $+4.5^{\circ} \mathrm{C}$. 
The described temperatures provide favorable conditions for frost action: the number of days with transition through $0^{\circ} \mathrm{C}$ ranges between 90 at $2000 \mathrm{~m}$ a.s.l. and 80 at $2900 \mathrm{~m}$ a.s.l., and the number of frost days (with minimum daily temperature below $0^{\circ} \mathrm{C}$ ) ranges between 170 and 260 respectively (according to data by Grunewald and Scheitchauer, 2008, 2011). In result, exposed ridges at altitudes above 2600-2700 $\mathrm{m}$ a.s.l. are strongly weathered, the surface layers of rock disintegrating into cobble-size blocks, and karstification in these areas is oppressed.

On the other hand, the great number of frost and icy days for cirque bottoms at 2200-2400 m a.s.l. (200-220 days with minimum temperature below $0^{\circ} \mathrm{C}$ and $110-130$ days with only negative temperatures, according to data by Grunewald and Scheitchauer, 2008) determines the 6-7 months of snow cover duration at these sites, whereby enhancing karstification there.

Another factor for these differences is also the much smaller precipitation which falls in the mountains of the eastern Balkans, compared to the western parts of the peninsula. Precipitation in Pirin is hard to estimate properly, as no rain gauge stations have been operating within the mountain for the last 35 years. Annual amounts for Vihren hut for the period 1958-1981 were about $1400 \mathrm{~mm}$ (Annual bulletins of IHM), while for 1957-1961 an average of $1020 \mathrm{~mm} / \mathrm{y}$ was registered in Golemia Kazan cirque (Popov, 1964). The rainfall record of Musala peak has demonstrated a considerable decrease from the period 1931-1970 $(1177 \mathrm{~mm})$ to present (836 mm for the period 1994-2016). However, this drop is partly due to technical reasons (a shift of the position of the rain gauge in the 1970 's) and the decrease is evaluated to be actually about 15\% (Nojarov, 2012). As a conclusion, annual sums of about 1000-1100 mm are supposed for the high mountain parts of Pirin (especially the area around Vihren Peak), with 2/3 falling in the period November-April.

The relatively small amount of precipitation acts as a limiting factor for the intensity of karst processes, especially on exokarst. For comparison, in the central ranges of the Dinarides annual sums of about 2500-2600 mm are estimated (500-600 mm solely in December) (Djurović, 2011).
Although barren rock surfaces are wide spread, especially at altitudes above $2400 \mathrm{~m}$ a.s.l., typical karren pavements are not observed in Pirin. On some old roche moutonnee within cirques the pattern of surface karstification shows similarities to "mosaic-limestone pavements" (Wilson and Fernández, 2013). Marble faces are also very poor on corrosion microforms. Abundant screes that cover the base of cirque headwall and side walls are made of blocks much coarser than what is typical for the limestone areas. On few sites such debris accumulations form single lobes, or series of lobes, which can be associated with permafrost occurrence and rock glacier activity (relict or even recent). The effect of corrosion on marble rocks is most obvious in the sinkholes on higher cirque floors (at 2300$2500 \mathrm{~m}$ a.s.l.) where snow retains for at least 6 months and melting is slowly going all the summer. Dissolution is progressing faster on the perpendicular pattern of cracks in the rocks, producing an "ice cream ball"-looking like morphology (Fig. 4). Shafts are another wide spread surface karst landforms in the area. Usually they are not wider than 1-3 metres. In higher cirque depressions most of them are full of snow all the year.

Despite the weaker expression of surface karst compared to high mountain Dinaric karst, due to the long snow cover duration and the great volume of meltwaters, subsurface karst in Pirin is well developed. 71 caves were found and mapped in the cirque Banski suhodol only, for the period 20002016. In 2016 explorers in the cave Banski suhodol 9-11, reached a record depth for all Pirin: $-353 \mathrm{~m}$ (www.heliktit.info).

Glacierets and summer snow patches are typical features of high mountain karst areas of Pirin. Their existence is favoured by the following factors, which act together: low temperatures (annual +2 to $0^{\circ} \mathrm{C}$ ); high albedo of the lightly coloured bedrock (white marble); drainage of meltwaters that does not favour basal melting of snow; great shading provided by the deeply incised relict glacial cirques; considerable (in some cases great) contribution of avalanche and windblown snow. These conditions have allowed for two glacierets to survive several centuries without complete melt (Grunewald, 
Scheitchauer, 2008, 2011; Gachev et al., 2009; 2016) at altitudes 500 to $700 \mathrm{~m}$ lower than the suggested climatic snow line, which is at present estimated to be at $3100 \mathrm{~m}$ a.s.l (Grunewald and Scheitchauer, 2010).

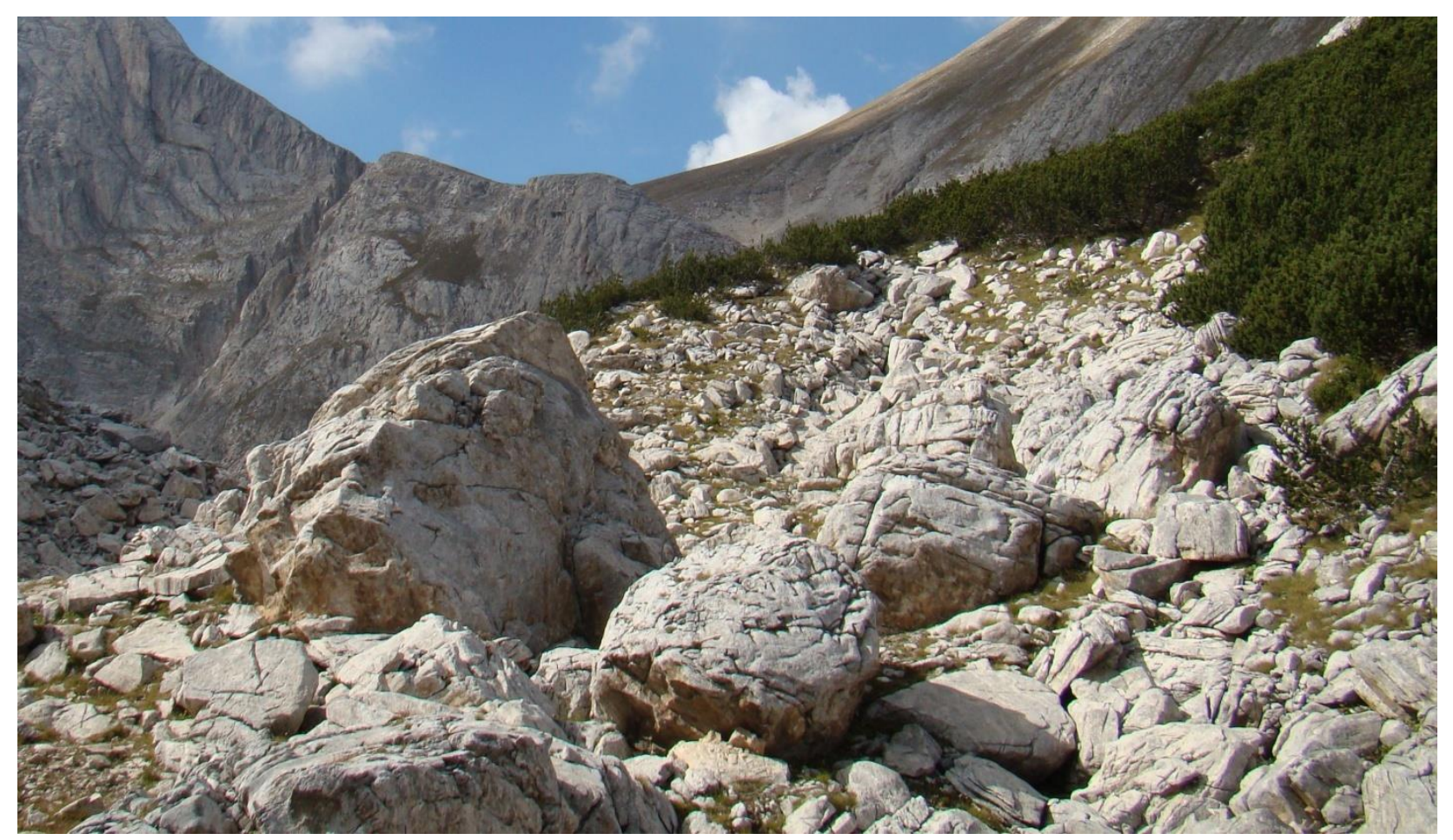

Figure 4 "Ice cream ball" stones on the floor of Golemia Kazan cirque

\section{Spatial structure and main features of high mountain karst}

\subsection{Vihren area}

This area is the largest in size, and the highest in altitude. In fact, it represents a monocline spreading from SE to NW, heavily eroded by former glaciers on the northeastern side, and much less affected on the southwestern (Fig. 5). The thickness of marble cover reaches $500-700 \mathrm{~m}$, with strata tilted towards NE (Marinova and Zagorchev, 1993). Five large "cirque-uvalas" are entirely comprised in the northerly facing slope in this section. They are deep but short, which is characteristic for glacier exaration in carbonate terrains, as the drainage of melt waters hindered, in part, the basal sliding of Pleistocene glaciers (and hence their downward movement as a whole). When combined with a great snow input, slow sliding resulted in overload of cirques with ice, and, as a consequence, depressions were overdeepened by glacial erosion. There are local variations in this model throughout the area.

A significant element that unites the spatial structure, is the main ridge, which is sharp along all its length, with almost vertical faces to $N E$, and surfaces tilted $35-40^{\circ}$ to $\mathrm{SW}$. All the peaks along this ridge have pyramidal form, mostly resembling truncated pyramids (Fig. 6). High slope section on the northern and eastern sides are rock faces 250 to $400 \mathrm{~m}$ high, with tilts above $50^{\circ}$ and straight cross section of the surface. The southwestern slope is an almost straight rocky and grassy surface, without traces of glacial rework (however, this slope seems to have sustained snow patches in nival depressions). Surface karst in these zones is only represented by barren rocky surfaces with scarce grassy vegetation, with no karren. A sinkhole on the very peak of Kutelo and a 5-6 metre deep shaft on the summit of Banski suhodol, have been formed probably by the corrosive action of the patches of windblown snow, or during the long ice free period 
when these summits were rising above the Pleistocene ice cover. Ridge top sections and southern slopes are highly weathered and covered with debris of mostly pebble and cobble size. Rocks on summits are disintegrated into loose blocks, which rest unstably on tilted surfaces. A distinctive characteristic of the main ridge is the very little dissection along the longitudinal profile: although very high, the ridge is completely passable on foot.
On the other hand, northern slopes are smoothened and made of solid rock (Fig. 7). The smaller temperature amplitudes here limit the rock disintegration, except the numerous corroded couloirs, which scar rock faces at places. The most prominent of them follow fault lines and represent mylonitic zones which may favour production of great amounts of scree material.

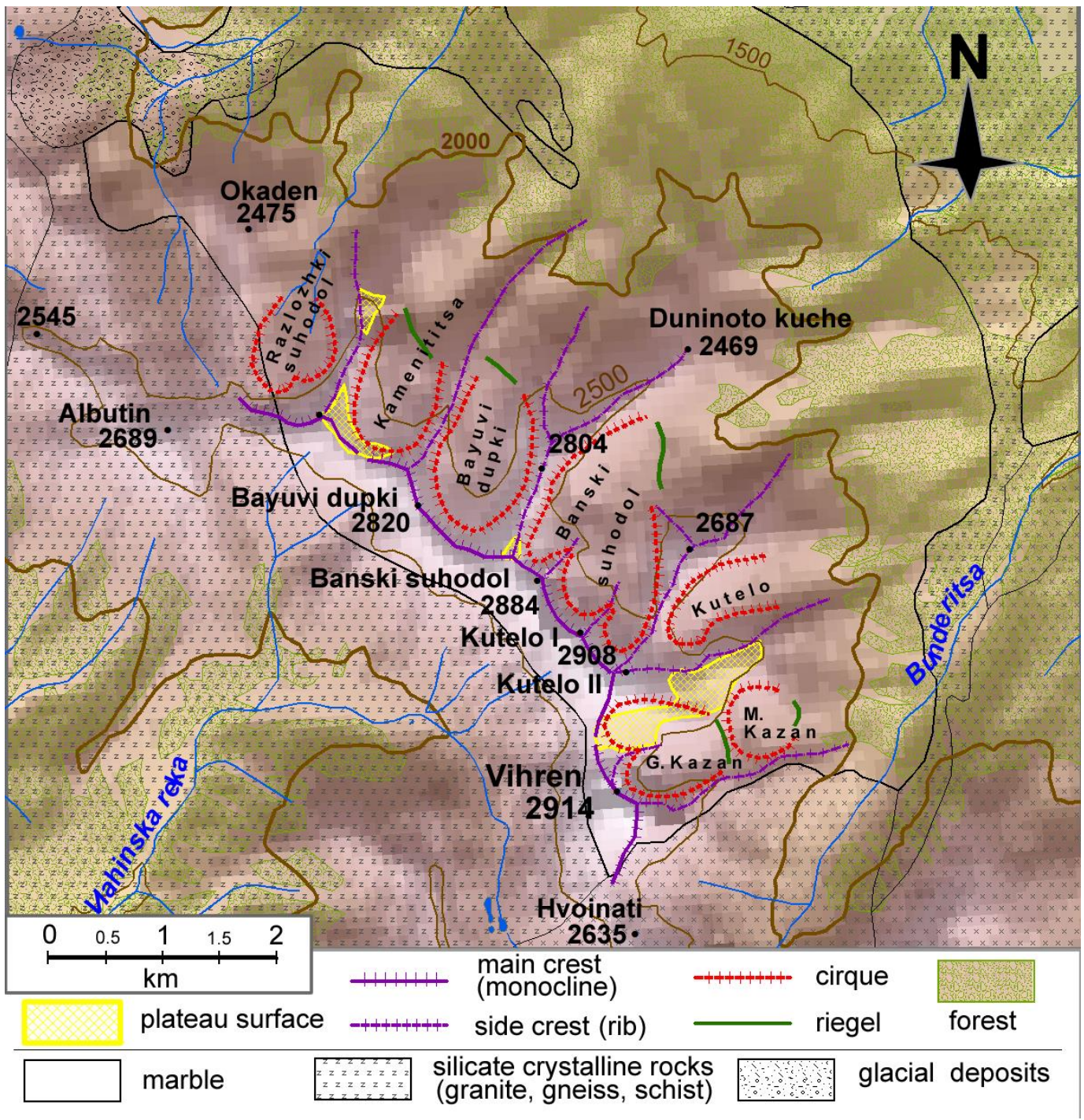

Figure 5 Map of Vihren area (rectangle 1 on Fig. 1)

Cirque bottoms lie on $2200-2400 \mathrm{~m}$ a.s.l., their highest sections are covered by screes and dotted by sinkholes. All glacierets and summer lasting snow patches are situated here, the most stable of them at the base of rock walls.
Golemia Kazan (the Great Pothole) is the southernmost of the five large cirques, and the deepest of all (Fig. 8). Its southwestern flank is the $450 \mathrm{~m}$ high rock face of Vihren Peak, the tallest in Pirin. The upper section of this wall, called Funiata 
(the Funnel) is tilted $60-70^{\circ}$, while the lower section is almost vertical (Popov, 1962). At the base of the wall lies the Snezhnika glacieret. It has a trapezoid shape facing the east, length 70-90 m and width 90 $100 \mathrm{~m}$. The drilling, made on this permanent form in 2006 (11 m deep to the base), revealed a glacier ice at depth about $10 \mathrm{~m}$, containing organic particles dated to be about 100 years of age (Grunewald et al., 2008; Grunewald and Scheitchauer, 2008, 2011).

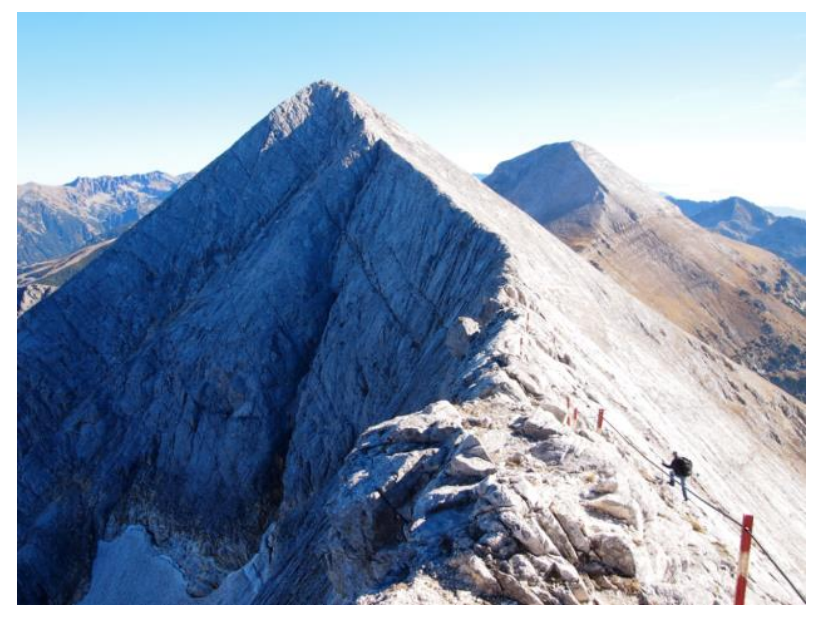

Figure 6 The main ridge of Northern Pirin within the marble area

On the basis of this evidence, and of its present permanency (weak trends of shrinkage in the last 23 years, Gachev, 2016), Snezhnika is now considered the southernmost glacial mass in Europe (Grunewald and Scheitchauer, 2010). Although in a partly sunny position, this small glacier (average area 0.55 ha) manages to retain a long-term stability due to its dependency on avalanche snow contribution, as the catchment area of the glacieret is 22 times larger than its surface.

Snezhnika is surrounded by a moraine crest $5-6$ $\mathrm{m}$ high from three sides. Radiocarbon dating of fossil soil particles in its base suggests it was modelled in its present shape during the Little Ice Age (Grunewald and Scheitchauer, 2008, 2011). Another, obviously older crescent shaped moraine is situated $150 \mathrm{~m}$ to the east, and several much older moraines mark the outlet of the cirque. The cirque bottom contains several sinkholes dotted in a line, which are filled by marble blocks. They represent features of covered karst typical for all cirques, similar to those described by Veress (2016) in the Dinarides. Blocks are rounded, with evident signs of corrosion. Above the lowest bottom section a grassy terrace is developed on the northern side, partly covered by scree material. Several round shaped sinkholes are formed here also. Two parallel tracks descend from the rockwall to the south. They were described as "avalanche rails" by Popov (1962), and in summer time they act as debris flow tracks.

Malkia Kazan lies to the NE. It represents a continuation of the glacial valley coming NE from Vihren peak. This is one big sinkhole, which grassy floor lies at $2200 \mathrm{~m}$ a.s.l. Surrounding slopes are steadier, with weak traces of karstification. A straight rocky ridge 3-5 m high surrounds cirque floor from the east, resembling the cirque riegel. Cirque bottom is entirely covered with grass, and shrubs of Pinus mugo grow on slopes.

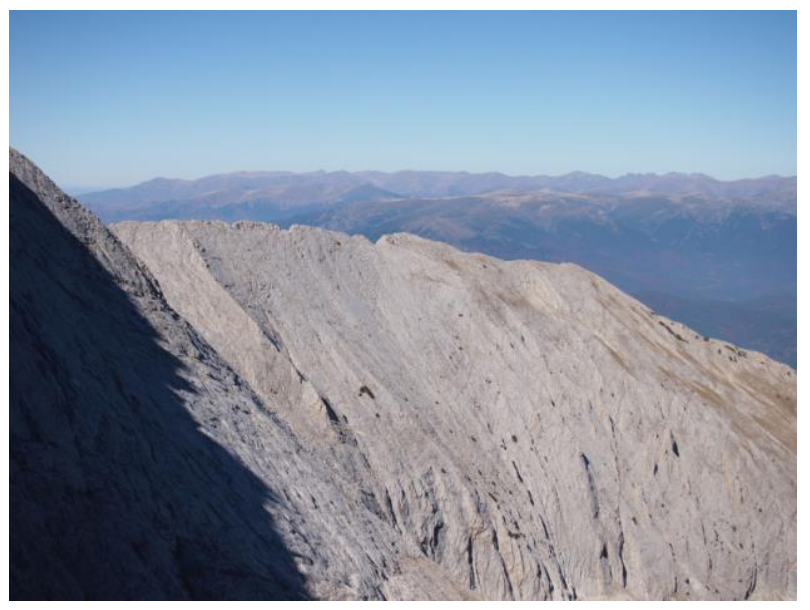

Figure 7 The smooth rock wall of Koteshki chal (Cats' ridge)

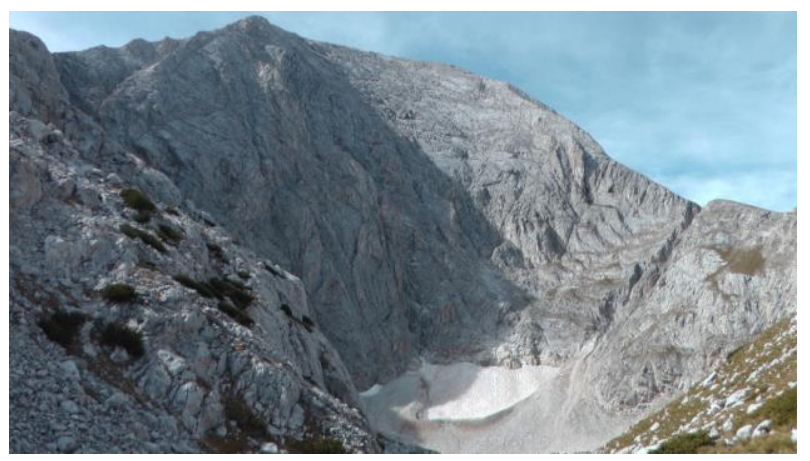

Figure 8 Golemia Kazan cirque with Vihren peak and Snezhnika glacieret 
Kutelo is the next cirque to the north. It is separated from Golemia Kazan and Malkia Kazan with a steady grassy field, dotted with some small sinkholes. The field must have stayed outside the extent of cirque glaciation, but probably was occupied by relatively thin snow/ice drifts during the Ice Ages, as a small nival depression is carved on the steady slope. Kutelo cirque is deep and relatively narrow, its uppermost floor section being entirely covered by debris. A crescent-shaped crest marks the spread of perennial snow patch (or glacieret?) that used to exist in the previous decades, and probably resembled a small glacier during the Little Ice Age. Below the crest grassy fields appear on the cirque floor. Now in September and October the entire cirque is completely dry.

The next cirque, Banski suhodol (Fig. 9), is the largest of all the five. This giant depression has a general NE aspect and an area of $2.3 \mathrm{~km}^{2}$ (Gachev and Gikov, 2010). Here the abrasive force of the former glacier acted parallel to marble strata, and this led to a weaker incision and a generally shallower cirque. In its upper part the cirque is divided into three sections. There exaration has formed depressions along a dyke of weaker rocks intruded in the marble, that runs in a direction parallel to the main ridge. In the centre of the cirque, to the north of the line of depressions there is a rough slope section, descending to a central and lowermost uvala at $2213 \mathrm{~m}$ a.s.l. The rough slope represents a labyrinth of sinkholes and small ridges and is dotted by numerous caves, most of which are vertical. To the east an intra-cirque $U$ shaped valley was formed by the retreating glacier, with a sequence of moraines left. The valley bottom is dotted by sinkholes, and its east slope covered by screes.

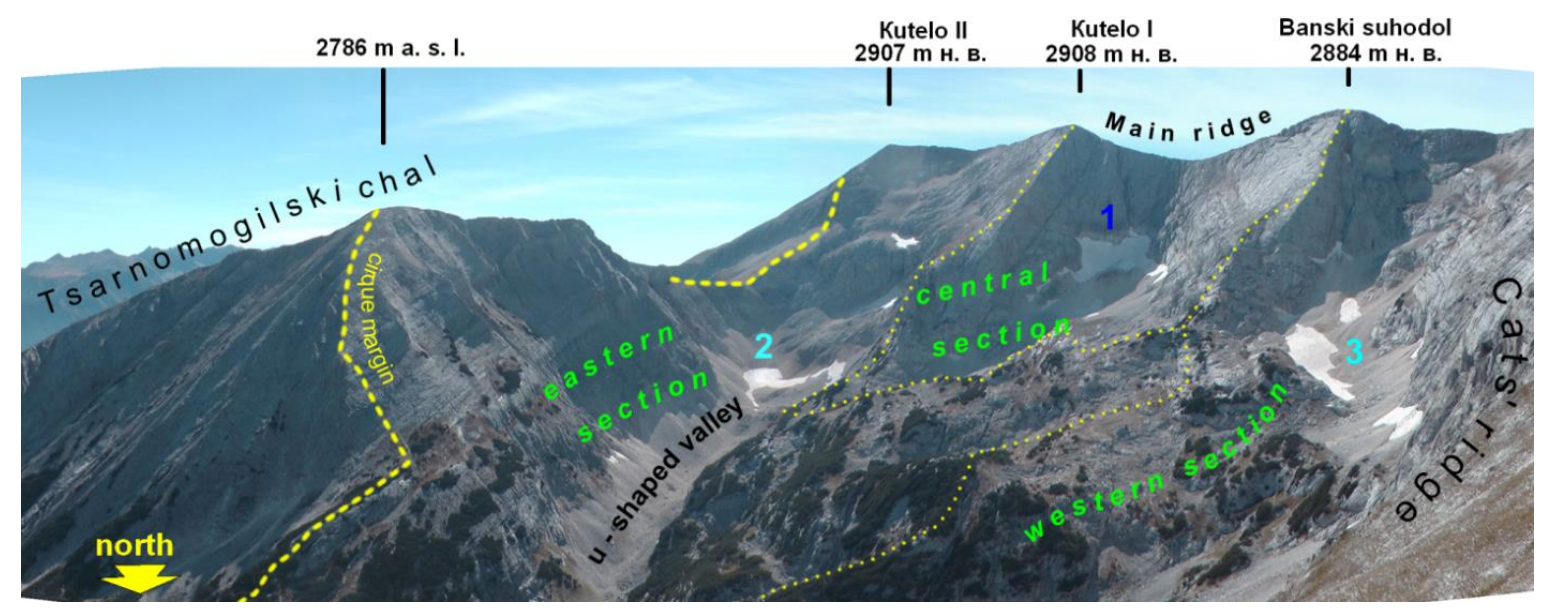

Figure 9 Banski suhodol cirque with permanent features of snow and ice: 1) glacieret, 2) and 3) snow patches. Dashed and doted lines mark the boundaries of the three cirque sections

Two snow patches and one glacieret are situated in the three upper sections (Fig. 10). The glacieret, which is in the middle one, has a high position, 2620-2700 $\mathrm{m}$ a. s. I., and lies in a rocky bed carved in the rock face between the peaks Kutelo I and Banski suhodol. The glacieret, which has an area about one ha, is still surviving due to the northern exposure and strong shading. It does not rely so much on avalanche snow, due to its much smaller avalanche area ratio (5.22 - the ratio between glacieret catchment area and ice surface). The geophysical survey done in August 2017 recorded a maximum firn/ice thickness of $17 \mathrm{~m}$ in the central part of the glacieret. Two parallel moraine ridges are formed at glacieret front, 4-5 m from one another. Considering the state of lichen cover and the overall appearance, the outer ridge is quite similar to the moraine that surrounds Snezhnika, and could possibly be addressed to the Little Ice Age. The internal, smaller ridge is lichen free, with light colour and a very fresh look, probably dating from the $20^{\text {th }}$ century. Another, well preserved moraine ridge, 
partly covered with soil and grass, is observed 200$250 \mathrm{~m}$ below the modern ice front. Morphologically it can be associated with the crescent moraine in Golemia Kazan.

The two snow patches in Banski suhodol cirque (Fig. 10) occupy scree covered sinkhole bottoms, and have been quite stable in the recent years.

Bayuvi dupki and Kamenititsa are the next two cirques to the west. They have similar morphology, in which the most specific is the lack of distinctive headwall. Instead, a steady slope rises to the main ridge. Due to this fact the bottom in the upper part is not covered by screes and bare rock is exposed and highly karstified. Vertical shafts down to several meters deep were formed in this area, which are filled with snow all year round (Fig. 10). The most expressive surface karst forms in Pirin are found in these cirques. In recent years it is usual that by the end of autumn cirque bottom becomes dry, but 60 years ago Peev $(1960,1961)$ reported about the presence of a small glacier up to $500 \mathrm{~m}$ long, which is now disappeared.

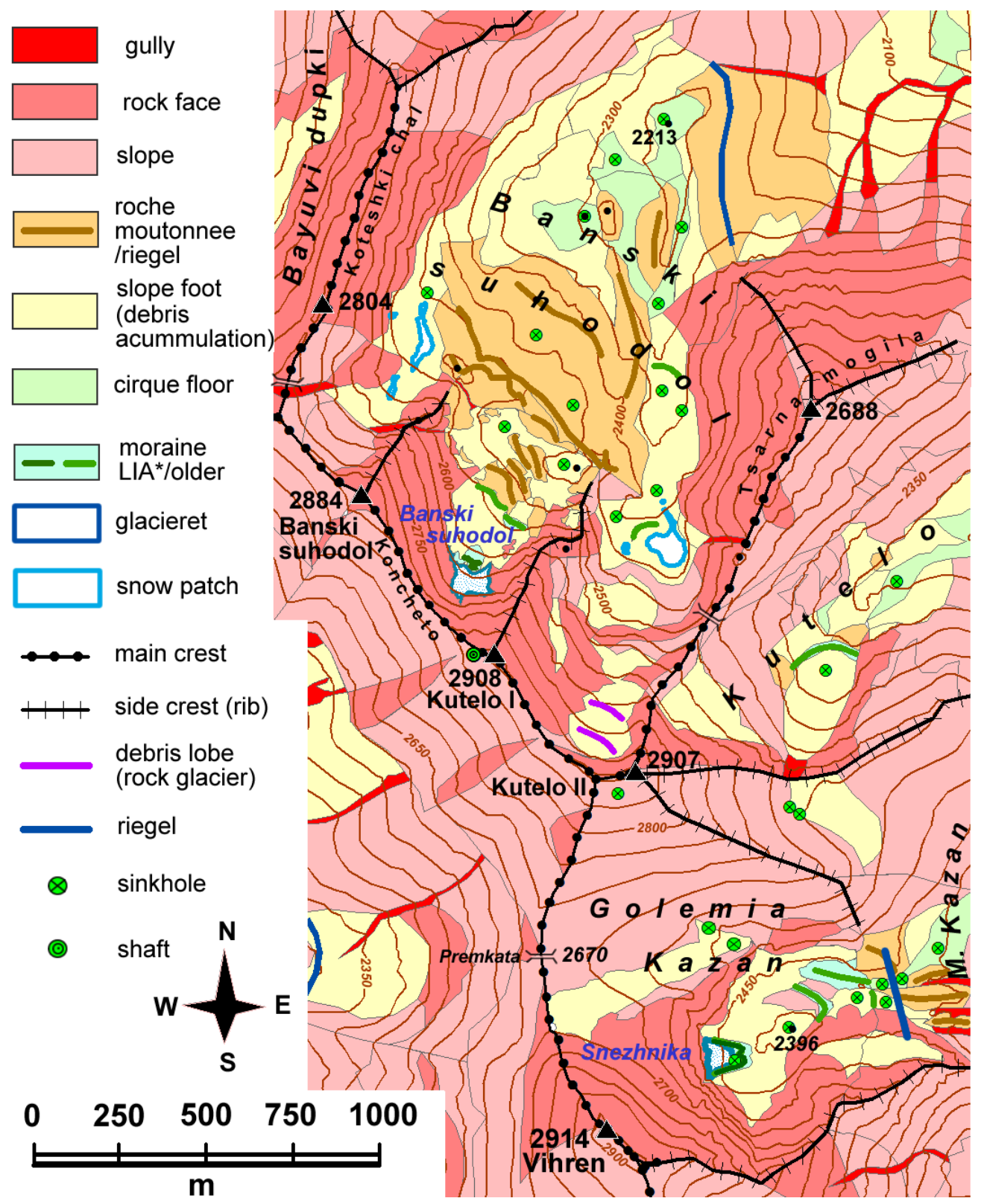

Figure 10 Geomorphological map of the cirques Golemia Kazan, Kutelo and Banski suhodol 


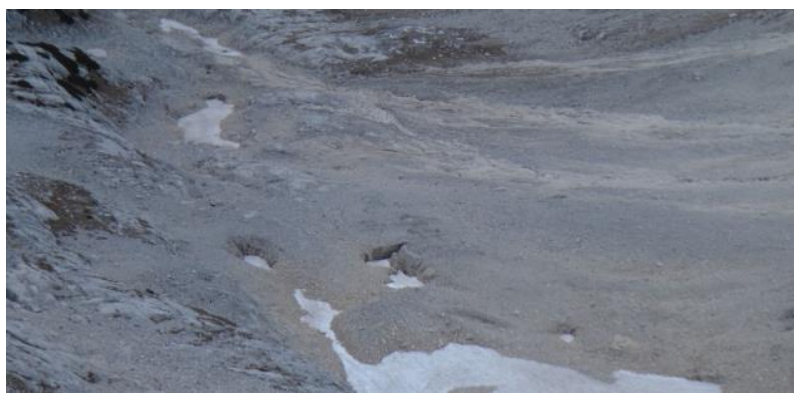

Figure 11 The floor of Bajuvi dupki cirque with vertical shafts and abraded rock. The site where was "the small firn glacier" described by Peev $(1960,1961)$. Picture taken in October 2013

The cirque of Razlozhki suhodol lies in the transition zone between marble and granite. The eastern slope is higher. This is a giant rock face of marble, which to the north descends with several toothed peaks, known as 'The stairs'. A line of large screes is running along the slope foot. On the contrary, the western slope, carved in granite, is steady, with a much lower altitude.

The granitic part of the bottom is filled with block material, which compose a chaotic pattern of ridges and furrows (not recognized as a rock glacier), which makes a great contrast to the karstic part. Figure 10 shows the typical morphology for the highest part of Northern Pirin. 50 to $70 \%$ of the slopes in the cirques Golemia Kazan and Banski suhodol have gradients above $40-45^{\circ}$ and can be categorized as 'rock faces'. Among all in the marble area, Banski suhodol is the cirque with the most complicated morphology of the floor, and the greatest abundance and variety of karst forms.

\subsection{Sinanitsa area}

The area around Sinanica peak (2517 $\mathrm{m}$ a.s.l.) lies in the western part of Pirin Mountains (Fig. 12, left). The marble is found at the south-eastern margin of the metamorphic mantle along its contact with the granitic body. Marble is exposed just in the area of the peak itself, and this gives it a prominent look from distance. Just one marble rock wall is present in the next cirque to the NE, Georgiitsa $(2589 \mathrm{~m}$ a.s.l.) (Fig. 13). The mixture of silicate and carbonate bedrock has created a mosaic relief of high diversity in the area.
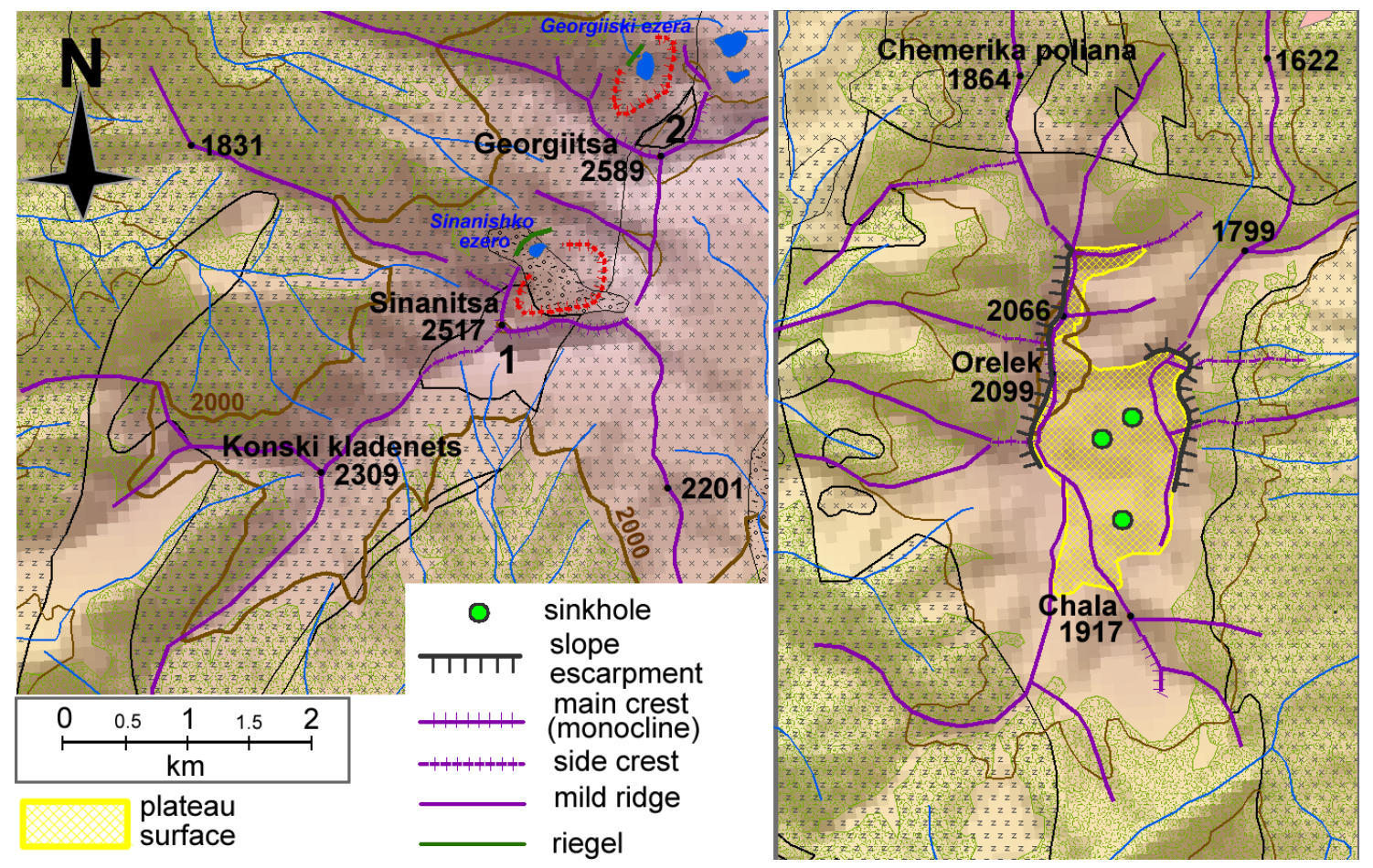

Figure 12 Map of Sinanitsa area (left) and Orelek area (right) (legend the same as in Fig. 5). Numbers indicate: 1. Sinanitsa marble area; 2 . Georgiitsa marble area. The lithology symbols are identical to those from the Figure 5 


\subsection{Orelek area}

The area of Orelek (Fig. 12, right) is much lower in altitude, and has a different character. This is a flattened grassy karst plateau with a smooth and rounded surface, dotted with shallow sinkholes. Marble layers sink to ENE, but in general their tilt is low. The western slope is quite steep and rocky, because denudation processes here acted transversely to layers tilt. Several side ribs are also formed on that slope. Similar situation is observed on the eastern slope, but tilts here are steadier. Epikarstic features on the surface of the plateau are presented by a dense pattern of sinkholes with steady slopes and grassy floors. Rock escarpments encompass the plateau from east and west. The western slope is the steepest and the longest. Several rocky ribs and gullies descend down on it.

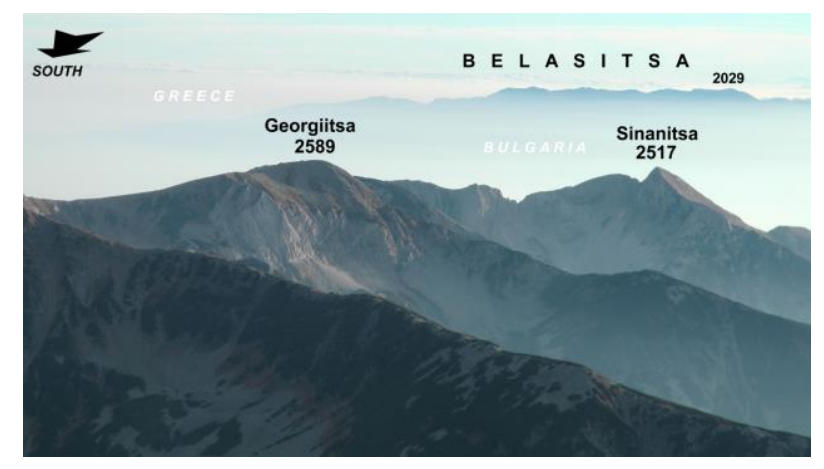

Figure 13 The peaks Georgiitsa and Sinanitsa seen from the north. The marble wall of Georgiitsa peak is visible

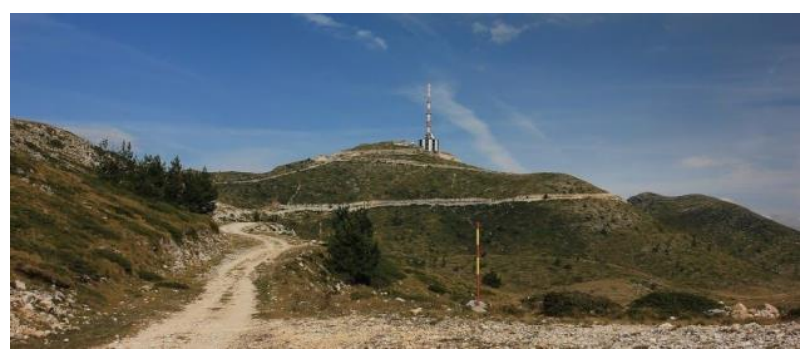

Figure 14 Orelek peak

\section{Evolution of high mountain karst relief}

Main factors for the development of high mountain karst in the Pirin Mountains have been the tectonic structure, the extensive action of glaciers during the
Pleistocene, and the specific structure of marble, which combines properties of carbonate and crystalline rocks together.

The initial formation of the geomorphological environment of the marble massifs of Northern and Central Pirin has a similar mechanism. Marble, which is less erodible than some of the surrounding rocks (Kanev, 1988; Georgiev, 1990, p. 340), remained higher than the neighbouring landscape, protecting the rocks below from denudation.

Contemporary high mountain karst relief has been formed in the course of many millennia. In high mountain conditions, the specific structural features of marble make so that weathering produces some amount of loose material due to crystalline defragmentation. So, if no other agent is present, the landscape tends to be smooth and grassy, with sporadic stone blocks and no traces of surface karst, except for some dolines with steady slopes. This is well demonstrated in the high mountain area of Orelek, which was under the snow line even in the strongest glacial phases of the Pleistocene. The long period upon which karst processes acted without interruption, and the flat surface that tend to retain snow for longer throughout the year, led however to the considerable development of subsurface karst, and a dense network of dolines on the surface. The mild landscape formed during this long evolution now shows a trend towards the rise of treeline.

The specific development of relief in the higher parts of Pirin can be traced back to the last Ice Age, at least the Wuermian period of the Pleistocene (Fig. 15). Dating of terminal moraines in the neighbouring Rila Mountains indicate that the largest extent of glaciers in the mountains of SW Bulgaria occurred in the beginning and the end of the LGM, 24 and 18 ka respectively (Kuhlemann et al., 2013). Although absolute dating is missing for Pirin, the same conclusion can be drawn for this mountain on the basis of the close proximity of both massifs.

So, during their maximum extent, Wuermian glaciers reworked large areas in the marble parts of Northern Pirin, mainly on the northern slope, where the snow line is estimated to have dropped to 2200 $\mathrm{m}$ a.s.l. (Kanev, 1990), thus producing glaciokarstic 
relief. In the valley of Bunderitsa, adjacent to, but mostly outside the marble area, the glacier in this period went down to $1100 \mathrm{~m}$ a.s.l., closely above the present day town of Bansko (Lilienberg and Popov, 1966). However, glaciation in the marble area was not so extensive in horizontal plan, due to the hard conditions which karstic rough terrain and the drainage of melt waters produced for the advance of glacier tongues. The smaller length was somehow compensated by overloading with ice mass and enhanced exaration in the accumulation zone, which produced some of the deepest cirques in Bulgarian mountains (e. g. Golemia Kazan). On the other hand, southern slopes were much less (or not at all) affected by glaciation, and contemporary landform features there are mostly of a structural origin. Besides the southern slope, some areas on and around the ridge tops were left outside the strong impact of glaciers. These represent remaining fragments of the old summit surface, rounded grassy fields on which sporadic epikarst forms (dolines and shafts) are scattered.

Figure 15 Scheme of the evolution of high mountain karst relief in the formerly glacierised areas of Northern Pirin: a) initial stage (prior to glaciation), in which soil and grass cover are well developed, and karst process is present, but suppressed (especially surface karst); b) glacial stage, in which the northern slope is subject to exaration, incision and exfoliation. Cirques are formed. Karst process runs only below the snow line, in open spaces and under 'warm' glacier ice; c) Late Glacial stage, in which lower parts of cirques are ice free. There karst develops intensively on barren rock. d) Younger Dryas/Onset of Holocene stage, in which glaciers go on retreating, and depressions below them that are close to rock walls are filled with debris (covered karst develops there). Karst remains intensive on uplifted parts of cirque bottom; e) present stage, in which ice (glacierets) exist only on the most optimal locations. On surfaces which have been recently freed from ice (red arrows) karst processes are still in the beginning. f) possible future stage, in which ongoing warming leads to a rise of treeline, eventual melt out of glaciers, and karstification of upper cirque parts. Light grey indicates the contour of the side ridge, and the red arrows on e) - areas with strong domination of physical weathering.
Within cirques, which are the major products of glaciation, the surface was exfoliated from weathering materials and soil cover, and, after the retreat of glaciers, was exposed to the corrosive action of snow and rain waters.
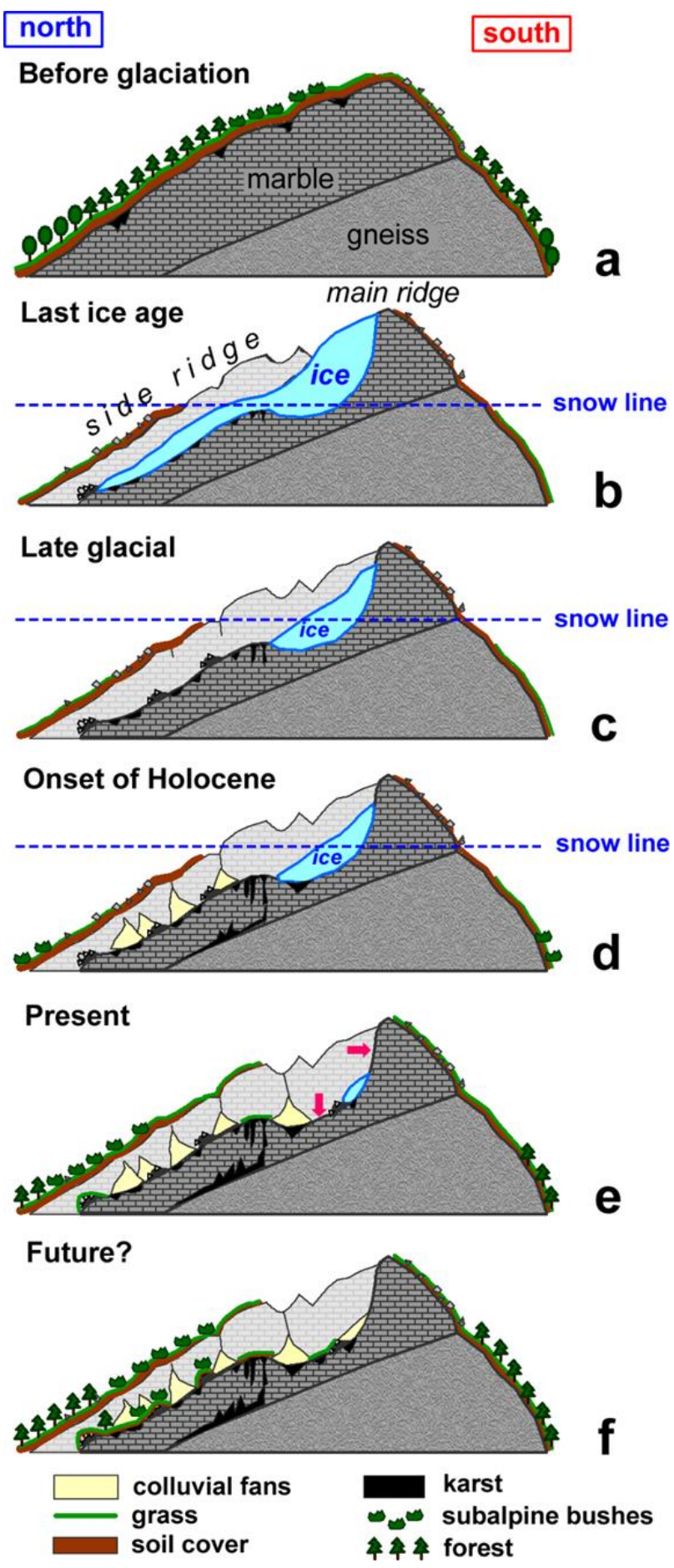
At the same time the enhanced contrast of topography, generated by former glaciers, produced favourable conditions for the occurrence of paraglacial processes, expressed mainly in rockfall and colluvial activity. In result the negative forms under the side and back walls of cirques were gradually filled with block material, and this once again limited the corrosive action of waters at the surface, turning the environment from open to covered karst. However, said fact did not trouble underground karst, and the generation of abyss caves and wells, which developed in sinkholes below the scree cover, and produced suffosion depressions on the surface.

The areas which are most prone to the development of surface karst are the elevated sections of cirque floors, such as roches moutonnées and riegels, distant from side walls, because they have remained outside the range of colluvial processes. During their existence, glaciers filled with sediment mostly the karstic depressions in their ablation zone, and much less those in the accumulation zone. This seems to be in force also for the cirques in the Pirin Mountains. The lowermost cirque floors, located at altitudes 2200$2300 \mathrm{~m}$ a.s.l. were at the end of the Wuermian glacial epoch, during the cirque phase of glaciers, sites where glacier tongues reached and terminated. Glaciers carried and deposited considerable amounts of coarse and fine sediment material which accumulated in these low altitude depressions, producing flat cover, now grown with dense grass. A considerable amount of peat is deposited on the floor of Malkia Kazan cirque. High cirque floors, situated at 2300-2500 m a.s.l., are now covered with coarse debris and are soil free. This provides better conditions for penetration of rain and melt waters and their corrosive action.

Already in Late Glacial times glaciers were preserved in the high cirque sections, and the low areas were subjected to paraglacial action and karstification. Depressions in the lower cirque parts were filled with finer sedimentary material, and this continued to cause a restrictive effect on the development of epikarst. With the progress of colluvial action, sinkholes in the upper unglaciated parts were filled with debris, and covered karst developed. As it is known from the studies of Ford and Williams (2007), Veress $(2010,2016)$ and others, the corrosive action of waters is dependent on the thickness of debris cover. In the case of glaciokarst the thickness of epikarst is down to several meters below the surface, so if the debris cover is thicker than 3-5 m the water will become already saturated when it enters the actual sinkhole.

Contrary to glacially reworked cirque depressions, conditions for karstification became optimal for the areas of the rigels and roches moutonnées that were freed from the ice. At present, these areas demonstrate stronger development of epikarstic landforms, and their appearance is similar to that of classical Dinaric karst (areas coloured in orange on Fig. 10 that have altitude below $2500 \mathrm{~m}$ a.s.l.).

In the higher cirque zones glaciers retreated later, probably after the Younger Dryas cold episode. Surface karst in these areas is much more weakly expressed. Shafts are the most spread in these locations. These karstic forms started to develop still under the ice, when, with rising temperatures, melting at glacier base gradually intensified. Roches moutonnées surfaces in these highest cirque sections look almost untouched by corrosion, and only signs of physical weathering are observed. The low temperatures, the relatively thin and not so long-lasting snow cover, and the short time which passed after their final deglaciation are the combination of factors that makes these areas one of the least affected by karstification.

On the ridge tops and in the highest cirque sections frost processes dominate. Small remains of former glaciers are still preserved in two locations, even in the conditions of present warming. Enhanced frost action in the highest parts produces large amounts of debris, which pile in rockwall bases and on the glacier ice.

In conditions of rising temperatures, the development of glaciokarstic relief will show trends towards further activation of rockfall and scree development in the highest areas, and stabilization of grass and bushy vegetation in the lower zones. The reduction of snow cover thickness and duration, and the overall decrease of precipitation will lead to decrease in karst activity, and the rise of the share of 
physical weathering in the geomorphic processes that shape high mountain relief.

In the course of the last two decades glacierets in Pirin demonstrate stagnation and relative stability (Fig. 16). One reason for this was the droughts in the 1990s, which made ice and snow cover shrinkage. The 2004-2010 period was characterized by increased winter snow accumulation, and this led to a positive balance and spatial increase of glacierets, despite the warming trends. The second decade of this century has been characterized by rising temperatures, decreased snow accumulation, and often abundant summer rains, which again caused glacier shrink. However, changes in Pirin glacierets have been much less expressed than those of glaciers in the Dinarides, which in the summer of 2017 were on the verge of disappearance. This is indicative for the more stable and balanced longterm climatic conditions in Pirin.
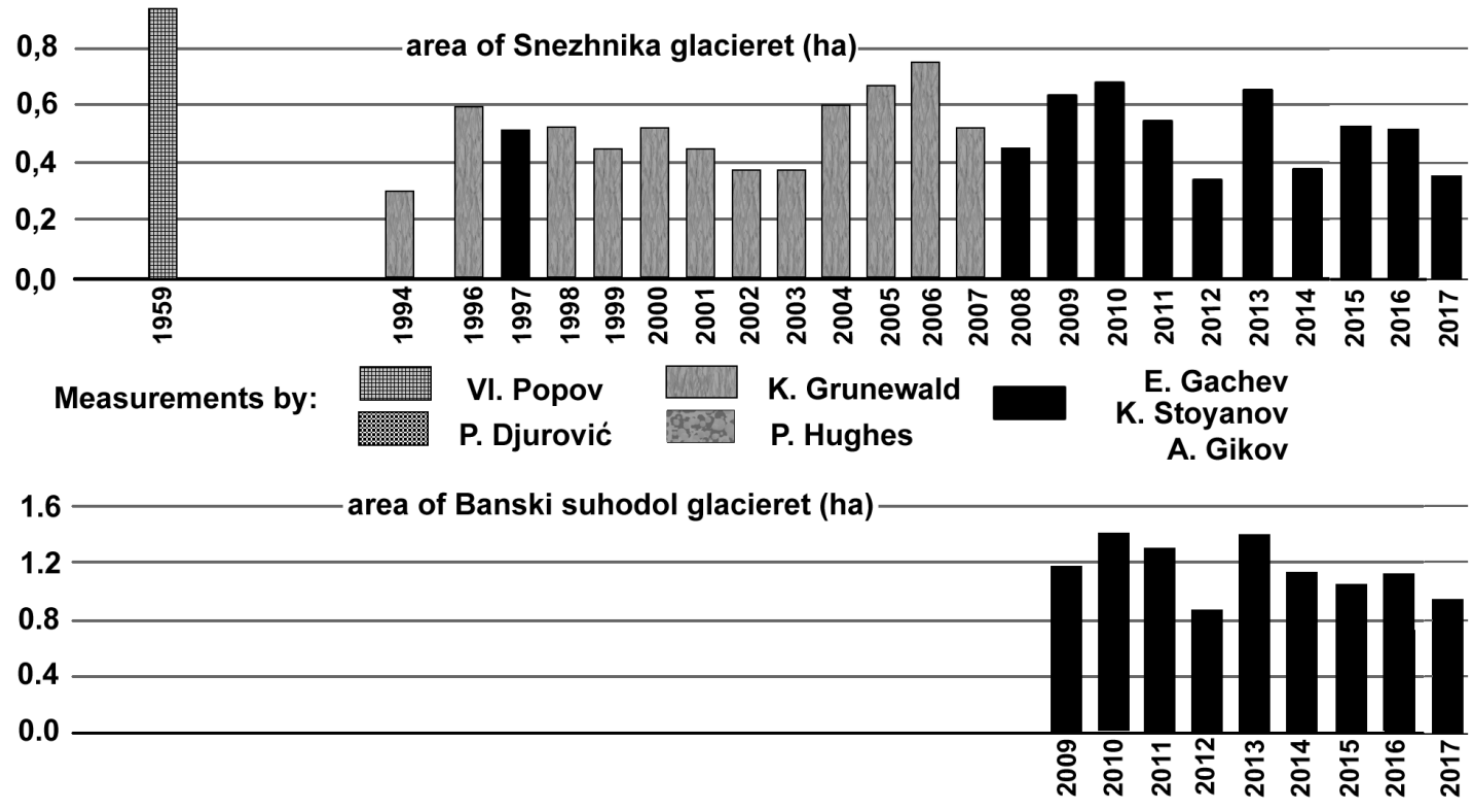

Figure 16 Areas of the glacierets Snezhnika (1994-2017) and Banski suhodol (2009-2017) measured in autumn (September-November), in the end of the balance year

\section{Conclusions}

High mountain karst is spread on three locations throughout the Pirin Mountains - around the peaks Vihren (to the north), Sinanitsa (to the west) and Orelek (to the south). If, as an altitude of the natural treeline, $2000 \mathrm{~m}$ a.s.l. is accepted for the lower limit of high mountain karst in the area, more than 9/10 of the high mountain karst areas are in the northern (Vihren) area. Karst in the high mountain zone of Northern Pirin can be categorized also as glaciokarst, as most of the territory was subject to glaciation during the Pleistocene. The most typical surface forms are the sinkholes with steady slopes (at lower altitudes) and the shafts (at higher altitudes). Being probably the most representative forms of classical epikarst, karren are not typical for the high mountain environment of Pirin, nor the corrosion microforms, which are wide spread in the Dinarides. Instead, corrosion of marble has produced "ice cream balls" in depressed areas where snow duration is longest.

In general, the high mountain karst in marble is typical with weaker surface expression of karst processes compared to the classical Dinaric karst, due to the coarser rock fragmentation of marble by physical weathering and the production of higher amounts of regolith. Another reason is the considerably smaller amount of atmospheric precipitation in Pirin (about 1000-1100 mm/y, 40\% 
of that in the high Dinarides). Subsurface karst is however well developed. It is presented by numerous caves, most of which vertical. Most of them contain seasonal or perennial ice.

The action of Pleistocene glaciers increased the potential for the development of surface karst by exfoliating the surface on northern slopes. The vast cirques formed there during Pleistocene glaciations are at the same time complex dolines (or uvalas). Surface karstification is strongest in the elevated areas of cirque bottoms, which are not covered by screes. Specific element of the high mountain karst complex in Pirin are the two glacierets (in fact small glaciers), which still survive despite the temperature rise, and even have demonstrated some stability in the last decades. At present, these are recognized as the southernmost glacial masses in Europe.

\section{Acknowledgements}

This research was supported by South-West University "Neofit Rilski" through the projects: SRP A10/15 "Complex research of present-day small glaciers on the Balkan Peninsula" (2015), RP A13/17. Research of high mountain climate through cryospheric indicators: glaciers and permafrost (2017), and project "Slovenia 01/2" of the National Institute of Geophysics, Geodesy and Geography, Bulgarian Academy of Sciences (2012-2014).

\section{References}

Annual bulletins of IHM, 1951-1981. Institute of Hydrology and Meteorology, Bulgarian Academy of Sciences, Sofia.

Djurović P. 2011. High mountain karst on Durmitor. Belgrade. 160 p. (in Serbian).

Djurović P, Petrović A, Simić S. 2010. Influence of Pleistocene glaciation over morphological diversity of uvalas in Durnmitor and Ziovo mountains. Bulletin of the Serbian Geographical Society, XC(1), Belgrade, 17-34 (in Serbian).

Ford D, Williams P. 2007. Karst hydrogeology and geomorphology. John Willey and Sons. Chichester. $561 \mathrm{p}$.

Gachev E. 2016. Climatic factors for the inter-annual dynamics of Snezhnika glacieret in Pirin. Proceedings of Conference "Geographic problems of territorial planning and utilization", Bulgarian Geographic Society, Varshets, 23-25 September, 26-38 (in Bulgarian).

Gachev E, Gikov A. 2010. A description and first measurement of the glacieret in Banski suhodol cirque. Problems of Geography, Bulgarian Academy of Sciences, 3-4: 90-98 (in Bulgarian).

Gachev E, Stoyanov K, Gikov A. 2016. Small glaciers on the Balkan Peninsula: state and changes in the last several years. Quaternary International, 415: 33-54.

Georgiev M. 1991. Physical Geography of Bulgaria. Sofia University Press. 406 p. (in Bulgarian).

Grunewald K, Scheitchauer J. 2008. Klima - und Landscaftgeschichte Sudosteuropas. Rekonstruktion anhand von Geoarchiven im Piringebirge (Bulgarien). Rhombos, Berlin. 180 pp.

Grunewald K, Scheitchauer J. 2010. Europe's southernmost glaciers: response and adaptation to climate change. Glaciology, 56: 129-142.

Grunewald K, Scheitchauer J. 2011. Landscape development and climate change in Southwest Bulgaria (the Pirin mountains). Springer, $162 \mathrm{p}$.

Grunewald K, Scheitchauer J, Gikov A. 2008. Microglaciers in Pirin mountains. Problems of Geography, Bulgarian Academy of Science, 1-2: 159-173 (in Bulgarian)

Grunewald K, Gachev E, Kast G, Nojarov P, Panayotov M. 2016. Meteorological observations in National park Pirin. Bansko, Sofia, Dresden, 24 p.

Ivanov Zh, Dimov D, Sarov S. 2000. Tectonic position, structure and tectonic evolution of the Rhodope massif. In: Ivanov Z. (ed.): Structure, Alpine Evolution and Mineralizations of the Central Rhodope area (South Bulgaria). ABCD-GEODE 2000 Workshop, Borovets, Sofia University, 1-20.

Kanev D. 1988. To the secrets of relief in Bulgaria. Narodna prosveta, Sofia. 152 p. (in Bulgarian)

Kanev D. 1990. Geomorphology of Bulgaria. Sofia University Press (in Bulgarian)

Kuhlemann J, Gachev E, Gikov A, Nedkov S, Krumrei I, Kubik P. 2013. Glaciation in Rila mountains (Bulgaria) during the Last Glacial Maximum. Quaternary International, 293: 51-62.

Kunaver J. 1983. Geomorphology of the Kanin mountains with special regard to the glaciokarst. Geografski zbornik, 22: 197-346.

Kunaver J. 2009. The nature of limestone pavements in the central part of the southern Kanin plateau (Kaninaki podi), Western Julian Alps. In: Gines A, Knez M, Slabe T, Dreybrodt W. (eds.): Karst Rock Features. Karren sculpturing, pp. 299-312, Zalozba ZRC. Institut za raziskovanie krasa ZRC SAZU, Postojna-Ljubljana, Carsologica 9. 
Lilienberg D, Popov V. 1966. New data about the glaciation of Pirin massif (Rhodopes). Doklady $A N$ SSSR, 167(5) (in Russian)

Maire R. 1978. Les karsts sous-glaciaires et leurs relations avec le karst profond. Revue de Geographie Alpine, 66: 139-148.

Marinova R, Zagorchev I. 1993. Geological map of Bulgaria, Sc. 1:100.000, map sheet Razlog explanatory note. Committee of Geology and Mineral Resources, Sofia (in Bulgarian).

Meneghel M, Sauro U. 1990. Reflection about high mountain karst environments and their fragility in the Dolomites. Acta crasologica XIX: 207-214, Ljubljana.

Nojarov P. 2012. Variations in precipitation amounts, atmosphere circulation, and relative humidity in high mountainous parts of Bulgaria for the period 19472008. Theoretical and Applied Climatology, 107(1): 175-187.

Peev H. 1960. Some present-day glacial features in the Pirin mountain. Priroda/Nature, 1 (in Bulgarian).

Peev H. 1961. A contribution to the issue about the formation of present-day glacial features in Pirin. Hidrologia i meteorologia (Hydrology and meteorology), 3: 22-26 (in Bulgarian).

Popov V. 1962. Morphology of the cirque Golemia Kazan, Pirin mountains. Izvestia na Geografski institut - BAN, VI: 86-99 (in Bulgarian).

Popov V. 1964. Observations on the glacieret in the cirque Golemia Kazan, Pirin mountains. Izvestia na Geografski institut-BAN, VIII: 198-207 (in Bulgarian).

Smart C. 2004. Glacierized and glaciated karst. In: Gunn J. (ed.): Encyclopedia of Caves and Karst Science, 389390. Fitzroy-Dearborn, New York, London.
Vatsev M. 2005. About the geological and geomorphological premises for the landslides of the western part of the Mesta graben in Gotse Delchev region (Southwest Bulgaria). Annual of the University of Mining Geology "St. Ivan Rilski", 48(1), Geology and Geophysics, 29-35 (in Bulgarian).

Vatsev M, Nedyalkova S. 1983. Composition of the Tertiary volcanites from Mesta graben. Annual Journal of VMGI, 30(2), Geology, 115-135 (in Bulgarian).

Veress M. 2010. Karst environments - karren formation in high mountains. Springer. Dodrecht, Heidelberg, London, New York. 230 p.

Veress M. 2016. Postglacial evolution of paleodepressions in glaciokarst areas of the Alps and the Dinarides. Zeitschrift fur Geomorphologie, 60(4): 343-358.

Wilson S, Fernandez F. 2013. National survey of limestone pavement and associated habitats in Ireland. Irish Wildlife Manuals, No. 73. National Parks and Wildlife Service, Department of Arts, Heritage and the Gaeltacht, Ireland.

Žebre M, Stepišnik U. 2014. Glaciokarst: a Case Study from the Dinaric Alps. Geophysical Research Abstracts, 16, EGU2014-2497, 2014

Žebre M, Stepišnik U. 2015. Glaciokarst landforms and processes in the Southern Dinaric Alps. Earth Surface Processes and Landforms, 40(11): 1493-1505.

www.helictit.info. Speleo club "Heliktit". Report about the commitment of speleoexpedition "Banski suhodol, 2016.

www.stringmeteo.com. Bulgarian site for discussing weather. 